\title{
Case Report of Sump Syndrome after Laser Conjunctivodacryocystorhinostomy
}

\author{
Ruchi Goel Divya Kishore Sushil Kumar Tushar Agarwal \\ Smriti Nagpal A.G. Apoorva \\ Maulana Azad Medical College, New Delhi, India
}

\section{Key Words}

Sump syndrome · Proximal canalicular block · Conjunctivodacryocystorhinostomy · Jones tube

\begin{abstract}
The sump syndrome was initially described in relation to patients who had undergone external dacryocystorhinostomy. Here we report a case of sump syndrome that developed following laser conjunctivodacryocystorhinostomy (CDCR) due to tube displacement after a bout of forceful sneezing. Unlike cases of external dacryocystorhinostomy where flaps are sutured, there is a potential space created by the sac remnants in laser CDCR. Hence, any displacement of the tube will lead to the improper drainage of secretions with superadded infections of the contents (as occurred in this case). Therefore, in laser CDCR, it is imperative to create an appropriately placed osteotomy with a correctly sized tube that is well secured to avoid displacement along with patient education regarding tube care.

(C) 2015 S. Karger AG, Basel
\end{abstract}

\section{Introduction}

The sump syndrome was first reported by Welham and Wulc [1] in 1987 in cases of failed dacryocystorhinostomy (DCR) where they described the radiological appearance of sac remnants in cases of unsuccessful lacrimal surgery. They evaluated dacryocystograms of these patients who were 'partially patent' and found a dilated sac with overflow of the dye into the nose. The sump syndrome is found to occur in cases where there are posterior flaps [2] or the ostium is situated too high. To solve this, an inadequate DCR with a small osteotomy [3] has been performed. Also, there is an increased chance of sump syndrome in proce-

KARGER 125/s $\quad \begin{aligned} & \text { Dr. Divya Kishore, MBBS } \\ & \text { C-48, Sector } 39 \\ & \text { Noida } 201301 \text { (India) } \\ & \text { E-Mail dr.divyakishore@gmail.com }\end{aligned}$


Goel et al:: Case Report of Sump Syndrome after Laser

Conjunctivodacryocystorhinostomy

dures such as balloon dacryocystoplasty and laser DCR, a flapless surgery in which there is an extensive contracture of the soft tissue anastomosis due to healing by secondary intention and fibrosis. In some cases, irrigation into the nose may seem normal [4], hence the need for a high index of suspicion in cases of early failure [3] after DCR.

All the previous reports of sump syndrome are in the context of DCR in patients with distal blocks. Here we describe a case of sump syndrome after conjunctivodacryocystorhinostomy (CDCR) in a patient with individual canalicular blocks, which has not yet been reported earlier to the best of our knowledge.

\section{Case Report}

A 48-year-old female presented with watering in the right eye for 3 years. She underwent syringing and probing in the right eye based on the findings of a proximal canalicular block at $3 \mathrm{~mm}$ in the upper canaliculus and a 4-mm one in the lower canaliculus. Hematological investigations, including hemogram, clotting profile, random blood sugar, and blood pressure, were within normal limits. Otorhinolaryngology clearance for performing a CDCR was assessed. She received topical ofloxacin $0.3 \%$ q.i.d. (Oflox, Cipla, Mumbai, India) in the right eye, and nasal drops of oxymetazoline $0.05 \%$ t.i.d. (Nasivion, Merck, India) in the right nostril 1 week before the surgery was planned.

On the morning of the surgery, the right nasal cavity was packed with ribbon gauze soaked in lignocaine 2\% and adrenaline (epinephrine) 1:200,000. The area around the medial canthus was infiltrated with a local anesthetic. She underwent CDCR with the placement of a Jones tube in the right eye using a semiconductor infrared diode $980 \mathrm{~nm}$ laser (Appasamy Associates, Chennai, India), with a power of $7 \mathrm{~W}$ in continuous mode. The tract was created from the caruncle to the medial wall using a von Graefe knife. An osteotomy of $6 \mathrm{~mm}$ in diameter was created using a diode laser, under endonasal endoscopic guidance. A Bowman probe was passed through the tract, and the length from the caruncle to the nasal septum was measured. A straight frosted Pyrex Jones tube (Aurolab, Madurai, India), inner diameter $0.3 \mathrm{~mm}$, outer diameter $0.6 \mathrm{~mm}$ with a plunge diameter of $4 \mathrm{~mm}$ and a length of 2 $\mathrm{mm}$ less than the measured length, was inserted, and the flange was sutured with 5-0 polyglactin 910. Syringing was performed to confirm patency, and the proximal end of the tube was visualized endoscopically to check for the correct placement of the tube at the root of the middle turbinate.

The immediate postoperative period was uneventful. She was discharged the next day and was advised to perform nasal douching with normal saline daily. She was followed up every 2 weeks. Syringing was done each visit, and complications, if any, were noted. The tract was patent for 4 weeks, after which the patient presented with congestion and a mucoid discharge from the right eye. She had an episode of forceful sneezing which had displaced the tube, and the flange was protruding out (fig. 1). There was swelling near the medial canthus with regurgitation on pressure from the tube and the peritubular area. She was prescribed ciprofloxacin $500 \mathrm{mg}$ b.i.d., topical ofloxacin $0.3 \%$, and tobramycin $0.3 \% 6$ times daily in the right eye. Her congestion resolved within 1 week. Two weeks later, she underwent an endoscopic examination where we found out that the medial end of the Jones tube was retracted inside the sac remnants. The Jones tube was removed, a laser probe was passed through the tract, and the osteotomy enlarged inferiorly. The tube was then refixed using a 6-0 polypropylene suture (Ethicon, Somerville, N.J., USA). The patient was prescribed topical ofloxacin $0.3 \%$ for 1 week, and she remained asymptomatic for the next 6 months. 
Goel et al.: Case Report of Sump Syndrome after Laser

Conjunctivodacryocystorhinostomy

\section{Discussion}

In its classical description, 'sump syndrome' has been defined in relation to external DCR when a residual in the nasolacrimal sac forms, collects fluids, and leads to tearing [6]. Welham and Wulc [1] concluded that pure ostium problems were the cause of failure in $52 \%$ of cases. An ostium which is created too low may be unable to bypass a mid or upper sac obstruction; an ostium that is too high creates a blind pouch from which tears cannot drain, and this collection may lead to an infection. Thus, the ideal ostium should remove all bone between the medial wall of the sac and the nose, leaving approximately $5 \mathrm{~mm}$ around the canaliculus free of bone.

According to Rose [5], the lacrimal system can be divided into 3 components, the lacus lacrimalis, the lacrimal sac, and the nasal space. The canaliculi and the nasolacrimal duct are poor hydraulic conductance conduits connecting these 3 compartments. A lacrimal sump syndrome and associated recurrent infections can occur if the lower portion of the bone surrounding the sac is removed inadequately. Lacrimal drainage surgery should convert the 3-compartment model into a 2-compartment model, with the elimination of the lacrimal sac and any possibility of 'volume' symptoms. In our patient, the sac was not completely removed, and the Jones tube had retracted into the sac, thus creating a blind pouch for the collection of tears and a subsequent infection (fig. 2).

Unlike external CDCR, where anastomosis is created between the sac and the nasal mucosal flaps, there remains a potential space for the collection in the lacrimal sac remnants in laser CDCR. A preexisting fibrotic mucosa is expected to occur in the patients with anatomical blocks. Furthermore, scarring by the laser burn with subsequent contraction of tissue could have worsened this situation. In our patient, the retraction of the Jones tube led to the collection of tears in the redundant sac, which led to a stagnation and eventual inflammation due to an ascending infection from the nasal cavity.

To the best of our knowledge, this complication has not yet been previously reported in cases of laser CDCR, and we recommend the creation of a large osteotomy at the appropriate location, not too high, and therefore ensuring an adequate fixation of the Jones tube preventing its migration. Also, patient selection and education is of utmost importance as inadequate postoperative care may result in the failure of the surgery due to tube displacement.

\section{Conclusion}

Sump syndrome can occur after laser CDCR if the tube retracts laterally. In our case, 1 month after surgery, the forceful sneezing resulted in tube displacement and the collection of secretions in the lacrimal sac remnants followed by secondary infection. The patient was managed by the administration of systemic and topical antibiotics along with inferior enlargement of the osteotomy and refixation of the tube.

\section{Disclosure Statement}

The authors declare no conflicts of interest. 
Case Reports in

Ophthalmology

\begin{tabular}{l|l}
\hline \multicolumn{2}{l}{ Case Rep Ophthalmol 2015;6:115-119 } \\
\hline DOI: $10.1159 / 000381450$ & $\begin{array}{l}\text { ○ 2015 S. Karger AG, Basel } \\
\text { www.karger.com/cop }\end{array}$ \\
\hline
\end{tabular}

Goel et al.: Case Report of Sump Syndrome after Laser Conjunctivodacryocystorhinostomy

\section{References}

1 Welham RA, Wulc AE: Management of unsuccessful lacrimal surgery. Br J Ophthalmol 1987;71:152-157.

-2 Rizvi SA, Sharma SC, Tripathy S, Sharma S: Management of traumatic dacryocystitis and failed dacryocystorhinostomy using silicone lacrimal intubation set. Indian J Otolaryngol Head Neck Surg 2011;63:264-268.

- Ari S, Kürşat Cingü A, Sahin A, Gün R, Kiniş V, Caça I: Outcomes of revision external dacryocystorhinostomy and nasal intubation by bicanalicular silicone tubing under endonasal endoscopic guidance. Int J Ophthalmol 2012;5:238-241.

4 Migliori ME: Endoscopic evaluation and management of the lacrimal sump syndrome. Ophthal Plast Reconstr Surg 1997;13:281-284.

5 Rose GM: The apparent paradox of 'success' in lacrimal drainage surgery; in Guthoff RF, Katowitz J (eds): Essentials in Ophthalmology, Oculoplastics and Orbit. Berlin-Heidelberg, Springer, 2007, pp 53-56.

6 Jordan DR, McDonald H: Failed dacryocystorhinostomy: the sump syndrome. Ophthalmic Surg 1993;24:692-693.
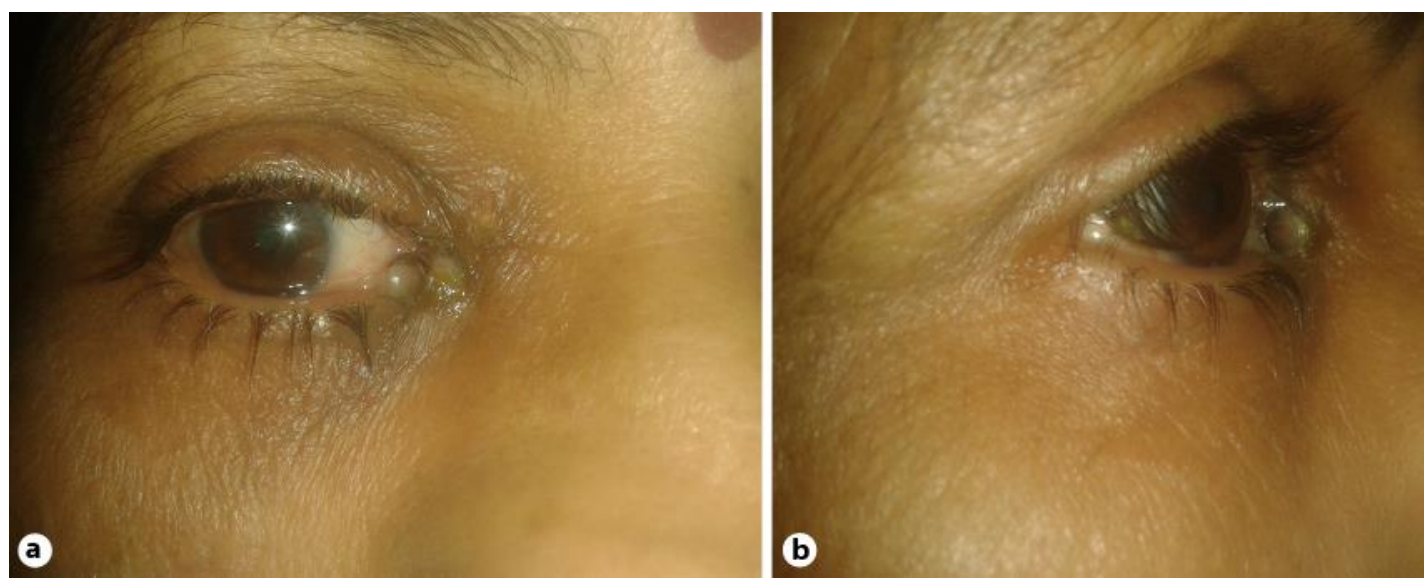

Fig. 1. a The patient presented with discharge and congestion, and the flange of the tube was protruding out. $\mathbf{b}$ Lateral view of the same patient. 


\section{Case Reports in \\ Ophthalmology}

\begin{tabular}{l|l}
\hline \multicolumn{2}{l}{ Case Rep Ophthalmol 2015;6:115-119 } \\
\hline DOI: 10.1159/000381450 & $\begin{array}{l}\text { ○ 2015 S. Karger AG, Basel } \\
\text { www.karger.com/cop }\end{array}$ \\
\hline
\end{tabular}

Goel et al:: Case Report of Sump Syndrome after Laser

Conjunctivodacryocystorhinostomy

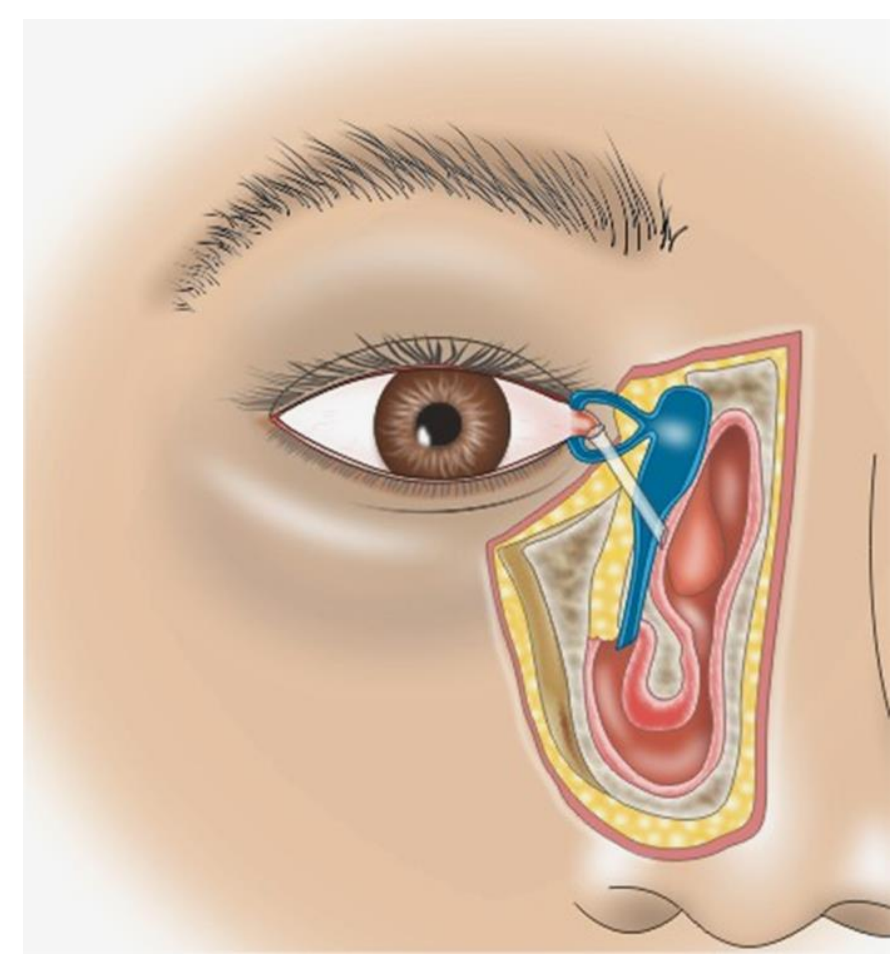

Fig. 2. Correct placement of the Jones tube. In our case, the tube had retracted into the sac remnants, thus creating a blind pouch for the collection of tears and subsequent infection. 